Zaitsev Ihor Petrovych, Kryshchuk Bogdan Stepanovych. Legal framework for training future naval infantry units officers using information and communication technologies. Journal of Education, Health and Sport. 2020;10(11):396-410. eISSN 2391-8306. DOI http://dx.doi.org/10.12775/JEHS.2020.10.11.040

https://apcz.umk.pl/czasopisma/index.php/JEHS/article/view/JEHS.2020.10.11.040

https://zenodo.org/record/5764972

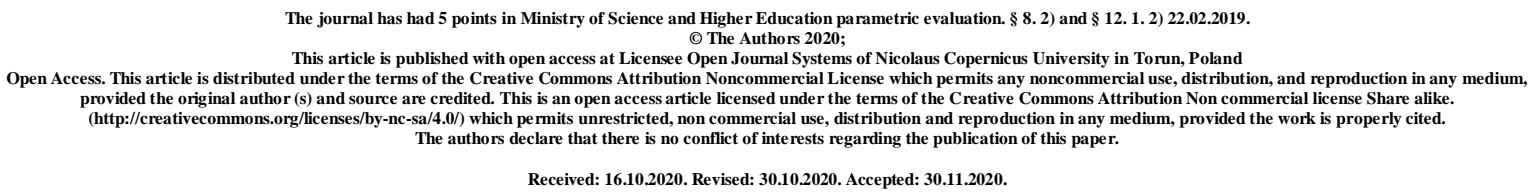

UDC 378.14

\title{
LEGAL FRAMEWORK FOR TRAINING FUTURE NAVAL INFANTRY UNITS OFFICERS USING INFORMATION AND COMMUNICATION TECHNOLOGIES
}

\author{
${ }^{1}$ Ihor Petrovych Zaitsev, ${ }^{2}$ Bogdan Stepanovych Kryshchuk \\ ${ }^{1}$ Military Academy (Odesa) \\ ${ }^{2}$ Khmelnytskyi Humanitarian-Pedagogical Academy
}

Ihor Petrovych Zaitsev, Military Academy (Odesa); Assistant Professor of Tactics and General Military Disciplines; zaicev2017@ukr.net; ORCID 0000-0002-0619-8148

Bogdan Stepanovych Kryshchuk, Khmelnytskyi Humanitarian-Pedagogical Academy; Assistant Professor of the Pedagogy Department, Candidate of Pedagogical Sciences (PhD), Associate Professor; kryschuk84@gmail.com; ORCID 0000-0002-9999-5356

\section{Abstract}

The generalizatin of the statesments of normative legal acts on the implementation of the tasks of informatization of the educational process, in particular, the use of information and communication technologies in the training of future naval infantry units officer is an urgent nessecity nowadays. The development and justification of organizational, legal, economic, financial, scientific and technical, methodological bases for organizing the educational process is one of the urgent tasks of creating legislation in the field of introduction of information and communication technologies in the educational process of higher educational institutions, including higher military educational institutions. The analysis of the current normative documents on the training of future officers in higher military educational institutions will give an opportynity to improve qualitatively the effectiveness of 
the educational process of training future naval infantry units officers.

Keywords: naval infantry units officer; information and communication technologies; training;legal framework.

\title{
НОРМАТИВНО-ПРАВОВА ОСНОВА ПІДГОТОВКИ МАЙБУТНІХ ОФІЦЕРІВ МОРСЬКОЇ ПІХОТИ ІЗ ЗАСТОСУВАННЯМ ЗАСОБІВ ІНФОРМАЦІЙНО- КОМУНІКАЦЙНИХ ТЕХНОЛОГІЙ
}

\author{
${ }^{1}$ Ігор Петрович Зайцев, ${ }^{2}$ Богдан Степанович Крищук \\ ${ }^{1}$ Військова академія (м. Одеса) \\ ${ }^{2}$ Хмельницька гуманітарно-педагогічна академія
}

Ігор Петрович Зайцев, Військова академія (м. Одеса); доцент кафедри тактики та загальновійськових дисциплін; zaicev2017@ukr.net; ORCID 0000-0002-0619-8148 Богдан Степанович Крищук, Хмельницька гуманітарно-педагогічна академія; доцент кафедри педагогіки, кандидат педагогічних наук, доцент; kryschuk84@ gmail.com; ORCID 00000002-9999-5356

Актуальною потребою сьогодення $є$ узагальнення положень нормативноправових актів щодо реалізації завдань інформатизації освітнього процесу, зокрема використання засобів інформаційно-комунікаційних технологій у підготовці майбутніх офіцерів морської піхоти. Одним із нагальних завдань щодо створення законодавства у сфері запровадження інформаційно-комунікаційних технологій в освітній процес закладів вищої освіти, зокрема і вищих військових навчальних закладів, є розробка та обгрунтування організаційних, правових, економічних, фінансових, науково-технічних, методичних засад організації освітнього процесу. Аналіз чинних нормативно-правових документів щодо підготовки майбутніх офіцерів у вищих військових навчальних закладах дасть можливість якісно підвищити ефективність освітнього процесу підготовки майбутніх офіцерів морської піхоти.

Ключові слова: офіцери морської піхоти; інформаційно-комунікаційні технології; підготовка; нормативно-правова основа.

Introduction. The development of the modern Ukrainian state requires building a competitive education system which will provide training for future specialists who are able to perform their functional and official duties qualitatively. Today, the training of highly 
qualified specialists in the security and defense sector is becoming important. According to this, higher military education in general, and higher military educational institutions, scientists, scientific and pedagogical workers of higher military educational institutions, representatives of state institutions in the field of defense in particular, direct their efforts to develop and improve the existing system of higher military education, taking into account the search for effective forms, methods, means of studying, improving the content component of professional training of future officers.

In connection with the processes of informatization of higher education, the problem of using information and communication technologies in the professional training of future officers of the Armed Forces of Ukraine is becoming increasingly important. In that context we note that the training of future officers of the Armed Forces of Ukraine, including future naval infantry units officers, requires legal regulation, which will ensure strict compliance with key standards of military training.

Therefore, now it is important to develop and improve the regulatory framework for training future naval infantry units officers in higher military educational institutions using information and communication technologies on the one hand, and to adhere to the norms of both international and domestic legal documents in the context of professional training of future officers of the Armed Forces of Ukraine - on the other.

Today, the training of future naval infantry units officers by means of information and communication technologies requires clear regulation and standardization. The analysis of the current legal documents on the training of future officers in higher military educational institutions will significantly increase the effectiveness of the educational process of training future officers of the Armed Forces.

Analisys of the previous publicacions. The issue of training future officers of the Armed Forces of Ukraine by means of information and communication technologies today is the subject of scientific studies of a number of scientists, such as: the formation of professional competence of future masters of military management with the use of simulation technology - L. Zaika (Zaika L., 2019); pedagogical conditions for the formation of information and communication competence in future officers - A. Kravchenko (Kravchenko A., 2019), innovative training technologies in higher military education of Ukraine - A. Motsa (Motsa A., 2017), formation of Informatics culture of future officers of land forces with the use of information and Communication Technologies-S. Radzikovsky (Radzikovsky S., 2014), readiness of future officers of the Armed Forces of Ukraine to use STEM technologies in professional activity O.Sviridiuk (Sviridiuk O., 2019), etc. 
However, despite a number of scientific publications which relate to various aspects of the introduction of information and communication technologies in the educational process of higher military educational institutions, it requires generalization of the statements of legal acts on the implementation of the tasks of informatization of the educational process, in particular the useing of information and communication technologies in the training of future naval infantry units officers.

Nowadays there is no study of the legal aspects of training future naval infantry units officers by means of information and communication technologies, which has been determined the relevance of our scientific research.

The aim of the article. The aim of the article is the analysis and generalization of the norms of domestic legal documents which relate to the professional training of future naval infantry units officers by means of information and communication technologies.

The main results. One of the urgent tasks of creating legislation in the field of introduction of information and communication technologies in the educational process of higher educational institutions, including higher military educational institutions, is the development and justification of organizational, legal, economic, financial, scientific and technical, methodological aspects of the organization of the educational process.

The importance of taking into account modern tendecies in informatization and computerization has been noted in a number of legal documents which relate to organizational, legal, economic, scientific and technical measures and at the level of central defense management bodies («The Conception of informatization of the Ministry of defense of Ukraine» (2014), «Military doctrine of Ukraine» (2015)), and at the level of organization of the educational process in higher military educational institutions («The Conception of military education in Ukraine» (1997), «Marine doctrine of Ukraine for the period up to 2035» (2009), «Conception of development of the security and defense sector of Ukraine» (2016), «Statements on the specifics of organizing educational activities in higher military educational institutions of the Ministry of defense of Ukraine and military training units of higher educational institutions» (2020), etc.

Futhermore, the main legal documents in the field of education - the Law of Ukraine «On education» (2017), «The Law of Ukraine «On higher education» (2014), the Law of Ukraine «On the National informatization program» (1998), the Law of Ukraine «On the Conception of the National Informatization program» (1998) also emphasize the importance of using information and communication technologies in the educational process of higher educational institutions, including in higher military educational institutions. This is explained 
due to the fact that information and communication technologies in education contribute to the qualitative improvement of the results of professional training of future specialists, including naval infantry units officers.

The importance of informatization of the educational process emphasize in a number of Decrees of the President of Ukraine, including: «On the National doctrine of Education Development»(2002), «On urgent measures to ensure the functioning and development of education in Ukraine» (2005), etc., as well as in Resolutions of the Cabinet of Ministers of Ukraine, among which: «State program «Information and communication technologies in education and science» for 2006-2010», etc.

For instance, the Law of Ukraine «On education», which generally regulates the activities of educational institutions, emphasizes the nessecity to form key competencies which are characteristic and necessary for each person, and among which it is important to form information and communication competence among students for education (the Law of Ukraine «On education»..., 2017). The Law of Ukraine «On higher education» defines the concept of «higher education» «as a set of systematized knowledge, skills and practical skills, ways of thinking, professional, ideological and civil qualities, moral and ethical values, other competencies obtained in a higher education institution», the acquisition of which should be ensured by the using of innovative methods and means of teaching, technologies, in particular and means of information and communication technologies in the educational process (the Law of Ukraine «On higher education»..., 2014).

The disclosure of the essence of informatization of the educational process in the Law of Ukraine «On the National informatization program» is further deepened. It considers under the concept of informatization a set of organizational, legal, political, social and economic, scientific and technical, and production processes which directed at creating conditions for meeting the information needs of citizens and society. Information needs are realized on the basis of the creation, development and using information systems, networks, resources and information technologies, which were built through the using of modern computing and communication technology. Here is the concept of «information technology» is interpreted as a purposeful organized set of information processes wih using computer technology that provides high-speed data processing, fast search for information, data dispersal, access to information sources regardless of their location «(the Law of Ukraine «On the National informatization program»..., 1998).

The mentioned above «National informatization program» reveals strategic planning for information support not only for education, but also for defense, national, cultural and 
other activities of national significance. This program is designed in such a way that its structure includes programs and projects of informatization at various levels: from national to local. According to it, state authorities should ensure informatization of science, education, culture, environmental protection and human health, public administration, national security and defense of the state, priority sectors of the economy; provide training of specialists in the field of informatization and information technologies (the Law of Ukraine «On the National informatization program»..., 1998).

The law of Ukraine «On the Conception of the National informatization program» emphasizes the importance of training highly qualified specialists, which is a component of the National information infrastructure and the main factor that ensures economic rising. According to the provisions of this law, informatization of strategic directions for the development of statehood, security and defense is achieved by creating and developing information and analytical, computing and automated systems, centers and networks that ensure the work of state authorities and local self-government bodies. Informatization of science, education and culture will be directed at the formation and development of the intellectual potential of the nation, improving the forms and content of the educational process, introducing computer methods of teaching and testing, which will make it possible to solve problems of education at the highest level, taking into account world requirements. As a result of the introduction of ideas of informatization of education, it is ensured: the development of human information culture (computer education); the development of content, methods and means of teaching to the level of world standards; reduction of the term and improvement of the quality of studying and training at all levels of personnel training; integration of educational, research and production activities; improvement of education management; personnel support of all areas of informatization of Ukraine by specialization and intensification of training of relevant specialistsFor the implementation these tasks, it is necessary to create a global computer network of education and science, which is implemented by automating the dissemination of information in the environment of higher education institutions, the development of educational, scientific, methodological literature in electronic form, the introduction of methods and software and hardware of distance learning (the Law of Ukraine «On the Conception of the National informatization program»..., 1998).

The ensuring of the effective using of information (multimedia and electronic learning tools), the creation of a network of information support for the educational sphere, the using of interactive teaching methods provides by the Decree of the President of Ukraine «On urgent measures to ensure the functioning and development of education in Ukraine» (Decree 
of the President of Ukraine «On urgent measures to ensure the functioning and development of education in Ukraine»..., 2005). The Decree of the President of Ukraine «On the National doctrine of education development» is aimed at the development of the material and technical base of higher educational institutions, providing them with computer equipment, introducing information and communication technologies in the educational process, systematic work on training and advanced training of scientific and pedagogical staff. The priorities of the state policy in this direction include: introduction of educational innovations, information technologies; creation of an industry of modern teaching tools, full provision of them to educational institutions; creation of a market for educational services and its scientific and methodological support; integration of domestic education into the European and world educational spaces. So, it is worth noting about the role of information and communication technologies in the context of ensuring equal access to education through the introduction of flexible educational programs and information technologies of training, namely: «The priority of education development is the introduction of modern information and communication technologies, which ensuring further improvement of the educational process, accessibility and effectiveness of education, preparation of the younger generation for life in the information society». (Decree of the President of Ukraine «On the National doctrine of education development»..., 2002). The conditions are created and the appropriate measures ar takn within their powers and competencies to informatize the educational process, including in the context of the material and technical aspect of this problem, by state institutions.

The State program «Information and communication technologies in education and science» for 2006-2010» focuses the attention on the need to introduce information and communication technologies in the field of education and science, since their creation and functioning will provide an opportunity to gain new knowledge, provide access to information resources for all participants of the educational process, which today is one of the conditions for a high-quality educational process This program provides the setting and solving a number of issues, in particular which related to providing educational institutions with computer and telecommunications equipment; improving the overall level of information literacy of educational students; activation of the introduction of information and communication technologies in the educational process and conducting scientific research, as well as providing access to domestic and foreign information resources, and the development of information security systems for the functioning of networks and information resources (State program «Information and communication technologies in education and science»..., 2005). 
Equally important for the disclosure of the legal framework for training future officers by means of information and communication technologies are documents related exclusively to the organization of the military education system. Thus, the aim of implementing the Conceptin of informatization of the Ministry of defense of Ukraine is determining the rules and procedure for solving the existing complex problem by building and using components of the information environment of the Ministry of defense of Ukraine, which related to the field of informatization, to meet the information needs of interested users» (the Conception of informatization of the Ministry of defense of Ukraine.... 2014).

The Marine doctrine of Ukraine for the period up to 2035, among other things, deals with the directions of development of the military and marine potential of Ukraine: the revival and development of marine aviation, coastal missile forces and marines, naval infantry units, military units of the branches of the armed forces and ensuring the Military Marine Forces of the Armed Forces by the way of bringing their structure and number in line with the tasks assigned to them and the level of threats. The development of the management system of the Military Marine Forces of the Armed Forces and Marine protection of the State border service of Ukraine expanding the capabilities of existing control systems of the Military Marine of the Armed Forces and Marine protection of the State border service of Ukraine is provided through the use of the latest information and telecommunications systems (Marine doctrine of Ukraine for the period up to 2035..., 2009). Therefore, in order to implement the tasks of the Marine doctrine of Ukraine, it is necessary to ensure the active using the information and communication technologies in the process of training future naval infantry units officers.

Considering the issue of the material and technical base of higher military educational institutions, the Conception of military education in Ukraine focuses on the activities to improve the quality of information component in the training of future military specialists through the creation of higher military educational institutions «computer information structures with access to external computer information networks», as well as on the dissemination of «functions of libraries of higher military educational institutions by converting them into information centers» (the Conception of military education in Ukraine..., 1997). In addition, predicting the development of military education, this document, among other things (optimization of the content of military education; integration of military and civilian education; introduction of new effective pedagogical methods, etc.) focuses on the creation of a system of medical and information support for the training of military specialists (the Conception of military education in Ukraine..., 1997). In line of this document, «the comprehensive improvement of the military education system, taking into account the needs 
of troops on the basis of general informatization of the educational process and the management system of military education, determining the effectiveness of the military education system, the quality of training of specialists» has been provided (the Conception of military education in Ukraine..., 1997). Also, «the development and implement the concept of informatization of the military education system, develop and implement an information system for ensuring the educational process and research work in higher military educational institutions» it is proposed among other things (the Conception of military education in Ukraine..., 1997).

According to the statements of the Military doctrine of Ukraine, «the main efforts are planned to focus on improving the level of combat and operative training of troops (forces) with a simultaneous radical updating of the control system and the quality characteristics of weapons and military equipment, including the adoption of fundamentally new models which developed on the basis of modern technologies» (Military doctrine of Ukraine..., 2015).

In the «Conception of development of the security and defense sector of Ukraine», the task is set in the context of the qualitative development of the security and defense sector: to introduce an integrated system of education, combat and special training of personnel in the security and defense sector with the involvement of teachers, instructors from NATO and EU member states, the formation of a new security culture while maintaining, if necessary, specialization and individualization of the personnel training system; improving the professional level of security and defense sector personnel; ensuring their high motivation to perform properly their assigned tasks (Conception of development of the security and defense sector of Ukraine.... 2016).

The current «Statement on the specifics of organizing educational activities in higher military educational institutions of the Ministry of defense of Ukraine and in military educational units of higher educational institutions» regulates the organization of the educational process in higher military educational institutions. This activity should be directed at organizing, providing (educational and methodical, personnel, information, material and technical (logistics) support, etc.) and implementing the educational process. Information support of educational activities in higher military educational institutions (military educational units of higher educational institutions) should provide for full, high-quality and operational library and bibliographic, information support for the training of military specialists, scientific and pedagogical, researcher staff and other categories of readers according to their information requests on the basis of wide access to book collections. The access to electronic information sources should be organized, which host electronic catalogs 
of publications and develop specialized services for access to electronic educational and methodological materials of departments using web technologies in libraries and structural units ( «Statesmens on the specifics of organizing educational activities..., 2020).

Considering that today independent work occupies an important place in the educational activities of institutions, the expediency of using means of information and communication technologies in its organization does not raise objections. The independent work of a cadet, attendee, student, adjunct is provided by information and methodological (textbooks, manuals) and material and technical (models, simulators, elements of weapons and military equipment) means which provided for in the subject program of the discipline. In addition, relevant scientific and professional educational literature is recommended for independent work of cadets, attendee, students and adjuncts ( $\ll$ Statement on the specifics of organizing educational activities..., 2020).

Another aspect of the organization of the educational process in higher military educational institutions is distance education, as an innovative form of education. Today, thanks to the development of information and communication technologies, representatives of many professions can be trained by means of distance education, since it functions on the basis of modern psychological and pedagogical, information and communication technologies ( «Statement on the specifics of organizing educational activities..., 2020).

According to the educational and professional training program for future naval infantry units officers at the Bachelor degree of higher education, the aim of studying is training highly qualified tactical-level officers who are competent in the military management of naval infantry units of the Military and marine forces of the Armed Forces of Ukraine links platoon, company and bear personal and professional responsibility for their actions. The student of higher education must choose the optimal forms, methods and aproaches training classes, apply psychological and pedagogical principles, methods (aproaches), means and technologies in solving professional problems, and to master the methodology of military training and upbringing. During the training, the student of higher education learns to use standard weapons and military equipment of naval infantry units of the Military and marine forces of the Armed Forces of Ukraine (Management of actions of naval infantry units..., 2020).

Conclusions. Therefore, the analysis of normative and law documents which related to the educational system in general and the professional training of future naval infantry units officers by means of information and communication technologies in particular, gives 
grounds to assert that their compliance and further improvement will make it possible to train high-quality personnel in the field of defense and security.

It is quite clear that achieving the goals of training a professional officer of the Armed Forces posesses important challenges for scientific and pedagogical staff of higher military educational institutions, because it is necessary to create such an internal information educational environment of the institution that could ensure the implementation of the key tasks of informatization of the military education system of Ukraine, namely: general informatization of the educational process with the aim to meet the educational and information needs of students; expanding the possibilities of distance education as a modern effective form of education; organization of library activities in educational institutions by means of information and communication technologies along with traditional means; development and active using of electronic textbooks, manuals, technical means of studying in the educational process; development of software products, the latest means of information and communication technologies, which for their level would correspond to world analogues and ensure the integration of the Ukrainian military education system into the global and European educational space.

Prospects for further research. We consider the justification of the structural and functional model of training future naval infantry units officers by means of information and communication technologies, as well as the search for ways to improve the content of professional training of the above-mentioned specialists, and improve the forms, methods, techniques of training future naval infantry units officers by means of information and communication technologies in higher military educational institutions of Ukraine are the prospect directions for further research.

\section{References}

Voienna doktryna Ukrainy: zatverdzh. Ukazom Prezydenta Ukrainy № 555/2015 vid 24.09.2015 r. (2015). Retrieved from: https://zakon.rada.gov.ua/laws/show/555/2015\#Text.

Derzhavna prohrama «Informatsiini ta komunikatsiini tekhnolohii v osviti ta nautsi» na 2006-2010 roky: zatverdzh. postanovoiu Kabinetu Ministriv Ukrainy № 1153 vid 07.12.2005 r. (2005). URL: https://zakon.rada.gov.ua/laws/show/1153-2005-\%D0\%BF\#Text.

Zaika, L. A. (2019). Formuvannia profesiinoi kompetentnosti maibutnikh mahistriv viiskovoho upravlinnia iz zastosuvanniam tekhnolohii imitatsiinoho modeliuvannia: avtoref. dys. ... kand. ped. nauk: 13.00.04. Kyiv. 
Zakon Ukrainy «Pro vyshchu osvitu»: pryiniatyi 01.07.2014 r. (zi zminamy). (2014). Retrieved from: https://zakon.rada.gov.ua/laws/show/1556-18\#Text.

Zakon Ukrainy «Pro Kontseptsiiu Natsionalnoi prohramy informatyzatsii»: pryiniatyi 04.02.1998 r. (zi zminamy). (1998). Retrieved from: https://zakon.rada.gov.ua/laws/show/75/98-\%D0\%B2\%D1\%80\#Text.

Zakon Ukrainy «Pro Natsionalnu prohramu informatyzatsii»: pryiniatyi 04.02.1998 r. (zi zminamy). (1998). Retrieved from: https://zakon.rada.gov.ua/laws/show/74/98$\% \mathrm{D} 0 \% \mathrm{~B} 2 \% \mathrm{D} 1 \% 80 \#$ Text.

Zakon Ukrainy «Pro osvitu»: pryiniatyi 05.09.2017 r. (zi zminamy). (2017). Retrieved from: https://zakon.rada.gov.ua/laws/show/2145-19\#Text.

Kontseptsiia viiskovoi osvity v Ukraini: zatverdzh. Postanovoiu Kabinetu Ministriv Ukrainy № 1410 vid 15.12 .1997 r. (1997). Retrieved from: https://zakon.rada.gov.ua/laws/show/1410-97-\%D0\%BF\#Text.

Kontseptsiia informatyzatsii Ministerstva oborony Ukrainy: zatverdzh. Nakazom Ministerstva oborony Ukrainy № 650 vid 17.09.2014 r. (2014). Retrieved from: https://zakon.rada.gov.ua/rada/show/v0650322-14\#Text.

Kontseptsiia rozvytku sektoru bezpeky i oborony Ukrainy: zatverdzh. Ukazom Prezydenta Ukrainy № 92/2016 vid 14.03.2016 r. (2016). Retrieved from: https://zakon.rada.gov.ua/laws/show/92/2016\#Text.

Kravchenko, O. I. (2019). Sutnist informatsiino-komunikatsiinoi kultury ta pedahohichni umovy yii formuvannia $\mathrm{u}$ maibutnikh ofitseriv $\mathrm{u}$ protsesi profesiinoi pidhotovky. Zbirnyk naukovykh prats Natsionalnoi akademii Derzhavnoi prykordonnoi sluzhby Ukrainy. Ser.: pedahohichni nauky, 4 (19), 197-209.

Morska doktryna Ukrainy na period do 2035 roku: zatverdzh. Postanovoiu Kabinetu Ministriv Ukrainy № 1307 vid 07.10.2009 r. (2009). Retrieved from: https://zakon.rada.gov.ua/laws/show/1307-2009-\%D0\%BF\#Text.

Motsa, A. A. (2017). Innovatsiini tekhnolohii navchannia u vyshchii viiskovii osviti Ukrainy: praktychne zastosuvannia. Internauka, 5, 26-34.

Polozhennia pro osoblyvosti orhanizatsii osvitnoi diialnosti u vyshchykh viiskovykh navchalnykh zakladakh Ministerstva oborony Ukrainy ta viiskovykh navchalnykh pidrozdilakh zakladiv vyshchoi osvity: nakaz Ministerstva oborony Ukrainy № 4 vid 09.01.2020 r. (2020). Retrieved from: https://zakon.rada.gov.ua/laws/show/z0250-20\#Text. 
Radzikovskyi, S. A. (2014). Vykhovannia informatsiinoi kultury maibutnikh ofitseriv Sukhoputnykh viisk iz zastosuvanniam suchasnykh informatsiinykh tekhnolohii. Visnyk Natsionalnoho universytetu oborony Ukrainy, 3, 138-143.

Sviridiuk, O. (2019). Sutnist ta struktura poniattia «hotovnist maibutnikh ofitseriv zbroinykh syl Ukrainy do zastosuvannia STEM-tekhnolohii u profesiinii diialnosti. Pedahohichnyi almanakh, 42, 162-169.

Ukaz Prezydenta Ukrainy «Pro Natsionalnu doktrynu rozvytku osvity»: pryiniatyi 17.04.2002 r. (2002). Retrieved from: https://zakon.rada.gov.ua/laws/show/347/2002\#Text.

Ukaz Prezydenta Ukrainy «Pro nevidkladni zakhody shchodo zabezpechennia funktsionuvannia ta rozvytku osvity v Ukraini»: pryiniatyi 04.07.2005 r. (2005). Retrieved from: https://zakon.rada.gov.ua/laws/show/1013/2005\#Text.

Upravlinnia diiamy pidrozdiliv morskoi pikhoty: osvitno-profesiina prohrama pershoho (bakalavrskoho) rivnia vyshchoi osvity (haluz znan 25 Voienni nauky, natsionalna bezpeka, bezpeka derzhavnoho kordonu; spetsialnist 253 Viiskove upravlinnia (za vydamy zbroinykh syl); kvalifikatsiia «Bakalavr viiskovoho upravlinnia pidrozdilamy morskoi pikhoty, ofitser taktychnoho rivnia». (2020). Odesa: Viiskova akademiia.

\section{Список використаних джерел}

Воєнна доктрина України: затвердж. Указом Президента України № 555/2015 від 24.09.2015 p. (2015). Retrieved from: https://zakon.rada.gov.ua/laws/show/555/2015\#Text.

Державна програма «Інформаційні та комунікаційні технології в освіті та науці» на 2006-2010 роки: затвердж. постаново. Кабінету Міністрів України № 1153 від 07.12.2005 p. (2005). URL: https://zakon.rada.gov.ua/laws/show/1153-2005-\%D0\%BF\#Text.

Заїка, Л. А. (2019). Формування професійної компетентності майбутніх магістрів військового управління із застосуванням технології імітаційного моделювання: автореф. дис. ... канд. пед. наук: 13.00.04. Київ.

Закон України «Про вищу освіту»: прийнятий 01.07.2014 р. (зі змінами). (2014). Retrieved from: https://zakon.rada.gov.ua/laws/show/1556-18\#Text.

Закон України «Про Концепцію Національної програми інформатизації»: прийнятий $\quad 04.02 .1998$ p. (зі змінами). (1998). Retrieved from: https://zakon.rada.gov.ua/laws/show/75/98-\%D0\%B2\%D1\%80\#Text.

Закон України «Про Національну програму інформатизації»: прийнятий 04.02.1998 p. (зі змінами). (1998). Retrieved from: https://zakon.rada.gov.ua/laws/show/74/98-\%D0\%B2\%D1\%80\#Text. 
Закон України «Про освіту»: прийнятий 05.09.2017 р. (зі змінами). (2017). Retrieved from: https://zakon.rada.gov.ua/laws/show/2145-19\#Text.

Концепція військової освіти в Україні: затвердж. Постановою Кабінету Міністрів України № 1410 від 15.12.1997 p. (1997). Retrieved from: https://zakon.rada.gov.ua/laws/show/1410-97-\%D0\%BF\#Text.

Концепція інформатизації Міністерства оборони України: затвердж. Наказом Міністерства оборони України № 650 від 17.09.2014 p. (2014). Retrieved from: https://zakon.rada.gov.ua/rada/show/v0650322-14\#Text.

Концепція розвитку сектору безпеки і оборони України: затвердж. Указом Президента України №92/2016 від 14.03.2016 р. (2016). Retrieved from: https://zakon.rada.gov.ua/laws/show/92/2016\#Text.

Кравченко, О. І. (2019). Сутність інформаційно-комунікаційної культури та педагогічні умови іï формування у майбутніх офіцерів у процесі професійної підготовки. Збірник наукових праць Національної академії Державної прикордонної служби України. Сер.: педагогічні науки, 4 (19), 197-209.

Морська доктрина України на період до 2035 року: затвердж. Постановою Кабінету Міністрів України № 1307 від 07.10.2009 p. (2009). Retrieved from: https://zakon.rada.gov.ua/laws/show/1307-2009-\%D0\%BF\#Text.

Моца, А. А. (2017). Інноваційні технології навчання у вищій військовій освіті України: практичне застосування. Інтернаука, 5, 26-34.

Положення про особливості організації освітньої діяльності у вищих військових навчальних закладах Міністерства оборони України та військових навчальних підрозділах закладів вищої освіти: наказ Міністерства оборони України № 4 від 09.01.2020 p. (2020). Retrieved from: https://zakon.rada.gov.ua/laws/show/z0250-20\#Text.

Радзіковський, С. А. (2014). Виховання інформаційної культури майбутніх офіцерів Сухопутних військ із застосуванням сучасних інформаційних технологій. Вісник Національного університету оборони України, 3, 138-143.

Свірідюк, О. (2019). Сутність та структура поняття «готовність майбутніх офіцерів збройних сил України до застосування STEM-технологій у професійній діяльності. Педагогічний альманах, 42, 162-169.

Указ Президента України «Про Національну доктрину розвитку освіти»: прийнятий 17.04.2002 p. (2002). Retrieved from: https://zakon.rada.gov.ua/laws/show/347/2002\#Text. 
Указ Президента України «Про невідкладні заходи щодо забезпечення функціонування та розвитку освіти в Україні»: прийнятий 04.07.2005 р. (2005). Retrieved from: https://zakon.rada.gov.ua/laws/show/1013/2005\#Text.

Управління діями підрозділів морської піхоти: освітньо-професійна програма першого (бакалаврського) рівня вищої освіти (галузь знань 25 Воєнні науки, національна безпека, безпека державного кордону; спеціальність 253 Військове управління (за видами збройних сил); кваліфікація «Бакалавр військового управління підрозділами морської піхоти, офіцер тактичного рівня». (2020). Одеса: Військова академія. 